\title{
What Whatsapp Status Enables Reseller to Do as Channel
}

\author{
Kusumah Arif Prihatna, Rosalin Ayal, Meutia Sistarani, Yunitasari Christanti
}

\begin{abstract}
This research aims to understand the phenomena that arise from WhatsApp users who utilize WhatsApp Status to market their products. This research focuses on the background capabilities of WhatsApp Status that allow resellers to market their products based on capabilities of WhatsApp Status as part of social media, as a channel to deliver the value proposition to the customer, and as a means of supporting engagement between sellers and buyers. The qualitative approach was carried out by involving selected active users of WhatsApp Status based on Snowball Sampling. This research identifies the significant capability of WhatsApp Status as the main digital marketing channel for resellers in marketing their products where WhatsApp Status allows attachment between resellers and customers while WhatsApp itself is the most used chat application. However, WhatsApp Status has limited functionality only as a marketing channel with all the capabilities of social media in general.

Index Terms: WhatsApp, WhatsApp Status, Attachement Theory, Digital Media, Channel, Marketing, Reseller
\end{abstract}

\section{INTRODUCTION}

WhatsApp Status is a feature from WhatsApp Messenger application that was launched on February 24, 2017, where users of this application can share text, photos, videos and animated GIFs that will disappear within 24 hours (WhatsApp, 2018).WhatsApp Status allows users to share content not only for individuals or groups but for each contact that stores user numbers in their respective address book (WhatsApp, 2018). WhatsApp Messenger itself is a chat application in the form of Mobile Instant Messaging (MIM) that provides text, images, location, video, and audio messaging services as well as video and audio calls using smartphones based on Android, Blackberry, iOS, Symbian (s60), and Windows Phone (Sahu, 2014).

Chat application, along with social media, is part of digital media, which is a means to deliver digitized content messages that can be sent via the Internet or computer networks (Couldry, 2012), which will continue to grow driven by the evolution and improvement of smartphones, along with a decrease in the cost and convenience of cellular data plans (Church \& de Oliveira, 2013). This development was accompanied by an increase in the number of social media users and chat applications via smartphones. In Indonesia today the number of social media users and chat applications via smartphone is 120 million people out of a total population of 256 million people. WhatsApp as a digital media is in the third place of often used applications under social media

Revised Manuscript Received on July 09, 2019.

Kusumah Arif Prihatna, Binus University, Jakarta, Indonesia

Rosalin Ayal, Binus University, Jakarta, Indonesia

Meutia Sistarani, Binus University, Jakarta, Indonesia

Yunitasari Christanti, Binus University, Jakarta, Indonesia applications Facebook and YouTube. But WhatsApp as a chat application lies in the first place as a frequently used application (Kemp, 2018). This allows WhatsApp users to use this application as a channel to achieve goals that allow a product to be known by being exposed to the target consumers to see the product (Ouwersloot \& Duncan, 2008).

This research involves Facebook, a social media that connects individuals, friends, or colleagues to interact, exchange photos, and send links and videos (Caers et al., 2013), also Instagram, a social media in the form of mobile applications for sharing photos that can commented by other users (Lee, Lee, Moon, \& Sung, 2015), as well as Bukalapak, an online marketplace in Indonesia that provides buying and selling facilities from consumers to consumers (Bukalapak, 2018), and OLX, a classified ad platform that provides marketplace in bringing together local communities to sell, buy, exchange unused goods, or offer services (OLX, 2018). The involvement of digital media was caused by several interviewees who use digital media as an option other than WhatsApp Status in providing value propositions to customers, and this situation was used to strengthen the role of WhatsApp Status.

This research was conducted to answer the research questions in revealing the background of resellers who utilize the WhatsApp Status feature as a channel in conveying the value proposition of the products offered to consumers where WhatsApp itself is the most widely used chat application in everyday life (Montag et al., 2015).

\section{LiteratURE REVIEW}

Researchers use the concept of media support that can affect marketing (Fill, 2009) which is associated with the attachment theory (Bowlby, 1969) which is used to understand the relationship between resellers and consumers in using WhatsApp Status as a channel in delivering the value proposition of products to consumers (Osterwalder \& Pigneur, 2010).

\section{1) Digital Media}

Digital media has many advantages over conventional media, supported by current conditions where smartphones and internet connections are things that can be obtained so that a message that is shared or a marketed product can spread quickly (Winer, 2009). Marketing through digital media has social characteristics which are a blend of 


\section{What Whatsapp Status Enables Reseller to Do as Channel}

digital information media and interpersonal connectivity (Mulhern, 2009) so that communication is not in the form of one-way communication but there is consumer involvement supported by the use of digital media itself (Karjaluoto \& Mustonen, 2015). Therefore digital media offers several things that allow users to influence marketing (Fill, 2009).

1) Interactivity, which is a condition where there are two or more parties who can communicate about the messages conveyed in more or less the same time through a media (Liu \& Shrum, 2002). Interactivity is an added value of digital media compared to traditional media where this is possible due to the advancement of information technology (Lister, Dovey, Giddings, Grant, \& Kelly, 2003).

2) Multichannel marketing, which is a marketing method using more than one marketing channel where the application of this method is to use a single strategy on various marketing channels that aims to maximize the possibility of getting consumers (Rangaswamy \& Bruggen, 2005).

3) Personalization, which refers to product adjustments and purchasing experience with individual consumer tastes based on personal information and their preferences (Chellappa \& Sin, 2005). The use of personalization can increase response rates, but it is necessary to understand the characteristics of attitudes and behavior of each audience towards the digital media used (Kaniewska-Sċba \& Pilarczyk, 2014).

4) Mobility, which is the ability to move or move freely and easily with the presence of wireless devices such as smartphones and the availability of Internet networks that allow transactions to be carried out in real time and in any location (Edwards, Ho, \& Choi, 2017).

5) Speed, which is related to the progress of information systems and technology that enables marketing communications to be carried out and delivered at a much faster speed than traditional media (Fill, 2009).

6) Efficiency, is something that refers to doing something right, whatever is done, is done in the most appropriate way, according to available resources (Sundqvist, Backlund, \& Chronéer, 2014).

7) Enhanced relationships, which is a matter that allows an increase in the level of a relationship while increasing customer desires for the unique characteristics found in a relationship, thus, in many situations, both sellers and consumers become more interested in conducting business transactions in a relationship (Palmatier, 2000).
8) Strategic Implications, which are influences on the main corporate planning that arise as a result of incomprehensibility and the ability to overcome the impact of the forces and dynamics of diverse changes that can often affect business from the point of view due to technological advances (Broch, Lurati, Zamparini, \& Mariconda, 2017).

WhatsApp is digital media so researchers have a point of view that WhatsApp Status as one of the WhatsApp features naturally has the parameters mentioned above. But empirically there may be digital media that does not meet these parameters as expected to support users in influencing digital marketing.

\section{2) Attachment Theory}

Basically attachment theory states that people innately form and maintain attachments to their supporters (or party that gives hope) to protect themselves from psychological threats (Bowlby, 1969). Currently attachment theory has developed which is associated with various contexts (Wu, Lu, Gong, \& Gupta, 2016). One of them is related to the context of emotional attachment between sellers, in this case resellers as users of WhatsApp, to other users as customers who can help increase customer loyalty and spread positive words of mouth (Vlachos, Theotokis, Pramatari, \& Vrechopoulos, 2010).

WhatsApp Status allows WhatsApp users to share content to anyone who saves mobile phone numbers between users so that it implies that between WhatsApp Status users are those who know each other. Content on WhatsApp Status is not intended for certain users or groups, and users can choose whether or not to view content. This implies that there is an emotional attachment between WhatsApp users who can see content in the hope of getting support from parties who know each other and avoid psychological threats.

\section{3) Channels}

Channels are a way of how resellers communicate the product selling value and deliver the product in several stages to the target customer (Osterwalder \& Pigneur, 2010)

4) Awareness, which is the way resellers generate target customer awareness about products or services. Resellers can take advantage of the promotional mix presented to the target customers so that they can be persuaded and motivated to consume the products offered, where one of the most widely used promotional mixes 
through digital media is advertising (Jordan, 2016).

5) Evaluation, which is the way the resellers help target customers evaluate the value proposition of the product. The target customer will evaluate the product or service that is

6) presented to them so that the reseller needs to provide media for the target customers to satisfy their curiosity in finding information about the product or service (Sullivan \& Kim, 2018).

7) Purchases, which is the way the resellers determine how target customers make the buying process. Purchases are made by various methods of payment from the customer's target to the reseller for the products or services that the target customer is interested in (Galloway, Rowbotham, \& Azhashemi, 2012). Purchases can be made by means of digital payments where payments are made through digital media $(\mathrm{Ng}, 2017)$.

8) Delivery, which is is the way resellers deliver products to target customers. The development of digital media today cannot provide a new way of delivering goods or services other than conventional methods (Fogli \& Ukei, 2005).

9) After-sales, which is the way resellers facilitates target customer responses to products. After-sales can boost business and improve the weaknesses of a business, therefore resellers need to provide channel for target customers to express their wishes or opinions about the products of goods or services offered (Brock, 2009).

\section{Methodology}

A qualitative approach was applied in this research toward interviewees in uncovering the phenomenon of digital media usage in the field of marketing (Bryman \& Bell, 2011) where this approach is useful for understanding and developing rich descriptions of the attitudes, perceptions, and behavior of the reseller as the people interviewed (Saunder, Lewis, \& Thornhill, 2015), which is appropriate at the time of data collection from the resellers itself (Daymon \& Holloway, 2010).

The qualitative approach in this research is an inductive method that relies on semi-structured interviews conducted in depth within the framework of conversations between interviewers and interviewees, while allowing flexibility (Bryman \& Bell, 2011). Besides interviews, research was conducted by means of passive participatory observation where observations are made without being involved in activities (Bryman, 2012) by paying attention to the advertisements posted on WhatsApp Status.

The interviewees are described as a purposive sample chosen to draw specific knowledge from the informant (Denzin \& Lincoln, 2003) regarding practices that are carried out, and in overcoming challenges that arise (Silverman, 2010). Interviewees were chosen based on NonProbability Sampling in form of Snowball Sampling where sampling techniques were carried out by not giving equal opportunity to each population element to be chosen as a source of data that was initially small and became larger (Kern, 2018).

Interviewees have been being WhatsApp Status active users to market products offered as resellers in their business fields. The age range of the interviewees is 30-35 years. The interviewees were initially only 3 reseller but eventually developed into 9 reseller because interviewee $\mathrm{A}$ recommended interviewees $\mathrm{A} 1$ and $\mathrm{A} 2$, and interviewee $\mathrm{A} 2$ recommended interviewee $\mathrm{A} 21$, then interviewee $\mathrm{B}$ recommended interviewees $\mathrm{B} 1$ and $\mathrm{B} 2$, then interviewee $\mathrm{C}$ recommended interviewee $\mathrm{C} 1$.

\begin{tabular}{|c|c|c|c|c|c|c|c|}
\hline No & $\begin{array}{c}\text { Inter } \\
\text { viewees }\end{array}$ & Gender & Business fields & $\begin{array}{c}\text { Have a } \\
\text { business } \\
\text { since }\end{array}$ & $\begin{array}{l}\text { WhatsApp } \\
\text { is used for } \\
\text { businesses } \\
\text { since }\end{array}$ & $\begin{array}{l}\text { Advertise via } \\
\text { WhatsApp } \\
\text { Status } \\
\text { since }\end{array}$ & $\begin{array}{l}\text { Other digital } \\
\text { media as } \\
\text { advertising } \\
\text { media }\end{array}$ \\
\hline 1 & A & Female & $\begin{array}{l}\text { Reseller: Food } \\
\text { and drinks }\end{array}$ & 2016 & 2016 & 2017 & $\begin{array}{l}\text { Facebook, } \\
\text { Instagram, }\end{array}$ \\
\hline 2 & A1 & Female & $\begin{array}{c}\text { Resellers: Bags, } \\
\text { Children's Shoes, } \\
\text { Kitchen } \\
\text { Equipment }\end{array}$ & 2016 & 2016 & 2017 & $\begin{array}{c}\text { Facebook, } \\
\text { Bukalapak, } \\
\text { OLX }\end{array}$ \\
\hline 3 & $\mathrm{~A} 2$ & Female & $\begin{array}{c}\text { Reseller: Purse, } \\
\text { Hijab }\end{array}$ & 2013 & 2014 & 2017 & $\begin{array}{l}\text { Facebook, } \\
\text { Instagram }\end{array}$ \\
\hline
\end{tabular}


What Whatsapp Status Enables Reseller to Do as Channel

\begin{tabular}{|c|c|c|c|c|c|c|c|}
\hline 4 & A21 & Male & $\begin{array}{c}\text { Services: Wash } \\
\text { Shoes Reseller: } \\
\text { Shoe } \\
\text { Cleaner }\end{array}$ & 2017 & 2017 & 2017 & $\begin{array}{c}\text { Facebook, } \\
\text { Instagram, }\end{array}$ \\
\hline 5 & B & Male & $\begin{array}{c}\text { Services: Catering. } \\
\text { Reseller: Muslim } \\
\text { clothes }\end{array}$ & 2017 & 2017 & 2018 & $\begin{array}{c}\text { Instagram, } \\
\text { Bukalapak }\end{array}$ \\
\hline 7 & B1 & Male & $\begin{array}{c}\text { Resellers: } 191 \text { Branded } \\
\text { Refill } \\
\text { Mineral Water, LPG } \\
\text { 3kg \& 12kg }\end{array}$ & 2017 & 2018 & 2018 & none \\
\hline 8 & Female & $\begin{array}{c}\text { Reseller: Make Up, } \\
\text { Bags, } \\
\text { Clothing }\end{array}$ & 2018 & 2018 & 2018 & $\begin{array}{l}\text { Instagram, } \\
\text { Bukalapak }\end{array}$ \\
\hline 9 & C1 & Female & $\begin{array}{c}\text { Services: Birthday } \\
\text { and Party Planner, } \\
\text { Catering } \\
\text { Reseller: Party } \\
\text { Supplies }\end{array}$ & 2016 & 2016 & 2017 & $\begin{array}{c}\text { Facebook, } \\
\text { Instagram, }\end{array}$ \\
\hline Reseller: Batik & 2015 & 2015 & 2017 & $\begin{array}{c}\text { Facebook, } \\
\text { Instagram, }\end{array}$ \\
\hline
\end{tabular}

Tabel 1. Intervewees Information

The case study research method was applied with selected sources based on the phenomenon under investigation where the case study itself is research by conducting in-depth exploration of programs, events, processes, activities, on one or more people (Kothari, 2004) which is presented descriptively by photographing social situations that will be examined thoroughly, broadly, and deeply (Creswell, 2014) and also comparative because it deals with domain comparisons (Vogt, Vogt, Gardner, \& Haeffele, 2014) between advertising through WhatsApp Status against WhatsApp Chat, Facebook, Instagram, Bukalapak, and OLX based on information obtained and processed.

Data taken from the interviewees were analyzed by applying the Miles \& Huberman Model which was carried out interactively and continuously until it was saturated, where the data was reduced, presented, and finally concluded (Kothari, 2004). But before reaching conclusions, the results of data analysis need to be conducted credibility test which is internal validity to achieve a high degree of trust in the research data (Vogt et al., 2014) by way of triangulation of sources where there are checks and matching of data obtained through several sources (Creswell, 2014)

\section{FINDINGS}

The interviewees have the same background as WhatsApp Status users who use WhatsApp Status as a channel to advertise products, which are based on technical aspects using the concept of media support that affects marketing (Fill, 2009), which is associated with the psychological side using the theory of attachment (Bowlby, 1969) in its function as a channel that conveys value propostion to target customer.

\section{A. Interactivity}

Interviewee A provided an implied definition of interactivity representing A1, A2, B2, C1 related to question and answer between resellers and customers.

\section{[...]many respond to my status, I chat back and}

there is a question and answer $[\ldots]$ Interviewee A2

emphasized that the response occurred on WhatsApp Chat.

$$
\begin{aligned}
& {[\ldots] \text { if anyone wants to know about the }} \\
& \text { hijab that I sell, the customer can } \\
& \text { immediately respond from Status that } \\
& \text { goes to Chat. }
\end{aligned}
$$

Interviewees tought that there was no interactivity on WhatsApp Status because the question and answer occurred on WhatsApp Chat, as stated by B representing A1, B2, and C1 for each product offered.

\section{[...] if anyone wants to know about the Muslim}

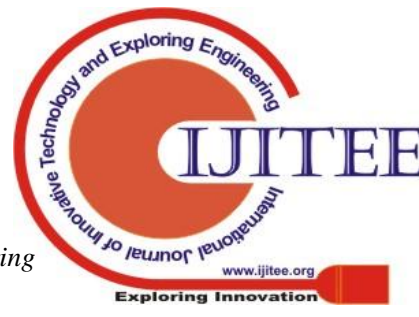



respond from Sstatus, then they can Chat via WhatsApp.

It was emphasized by interviewee $\mathrm{A}$ that the interaction occurred on WhatsApp Chat, while the advertisement was on WhatsApp Status.

\section{Before WhatsApp Status existed, I offered my merchandise to people or groups on WhatsApp who could chat immediately. After WhatsApp Status is available, I offer merchandise on WhatsApp Status which can also be replied via chat because it is connected to WhatsApp Status.}

Interviewee $\mathrm{C}$, representing other Instagram users, had the opinion that Instagram allows interactivity in comments and direct message features.

\section{[...] on Instagram, the advertised product can be directly commented on by followers, and usually I also reply to questions in direct message.}

Interviewee A2, representing other Facebook users, had the opinion that Facebook allows interactivity on comments and direct message features such as Instagram.

\section{[...] I like to advertise on Facebook. Followers like to comment. Sometimes I ask them through the personal message just to know if they see my merchandise.}

Interviewee A1 had the opinion that a marketplace like Bukalapak allows for interactivity, but it is different from OLX which has no interactivity

\section{[...] at Bukalapak, customers can chat with me. Whereas at OLX, customers are given seller numbers which are usually contacted via WhatsApp.}

Interviewee B, representing B2 as Bukalapak users, also shared the opinion that Bukalapak allows for interactivity.

[...] if anyone asks for a product at Bukalapak, they can chat $[\ldots]$

\section{B. Multichannel Marketing}

Interviewees had the opinion that multichannel marketing is a way of marketing products on a media that can be connected to other marketing media, as expressed implicitly by interviewee A representing A2 and C: clothes that I sell, the customer can immediately

\section{[...] I can provide links}

to Instagram or Facebook via

WhatsApp [...] It was supported

by the opinion of interviewee A1,

representing B and B2.

[...] for some of the products that I sell at Bukalapak, I give the link for those who want to know product details [...]

Interviewee agreed that WhatsApp Status allows multichannel marketing in text form only, this opinion was represented by interviewee $\mathrm{A}$.

I have never posted links to other social media on WhatsApp Status. I prefer to advertise on WhatsApp Status. From what I know, it can't be done if you use pictures, but it's possible if it's in writing, but the ads will be unattractive.

Instagram and Facebook allow multichannel marketing, as revealed by interviewee A21 representing other interviewees who use those digital media.
I post photos on Instagram that I can link to Facebook, and I can also share on WhatsApp. Facebook cannot share content but can input hyperlinks. On WhatsApp Status you can't input hyperlinks [...]

Bukalapak and OLX allow multichannel marketing by providing information via hyperlinks as expressed by interviewee A.

\section{[...] in Bukalapak or OLX, it can be connected to other media by entering the address link. WhatsApp Status cannot be connected to Bukalapak and OLX.}

\section{Personalization}

Personalization is related to how to convey product information through WhatsApp Status relating to customer characteristics. This definition was represented by the opinion of $\mathrm{B} 2$ representing $\mathrm{A} 1$ and $\mathrm{A} 2$.

\section{[...] because the average person I know}

$$
\begin{aligned}
& \text { is young } \\
& \text { mothers, so I put } \\
& \text { a photo that }
\end{aligned}
$$




\section{What Whatsapp Status Enables Reseller to Do as Channel}

makes them want to ask questions about cosmetics, or bags and clothes.

Several other interviewees provide an understanding of personalization related to answering questions privately through WhatsApp Chat regarding products tailored to customer personalization. This opinion was expressed by $\mathrm{B}$ representing resource persons $\mathrm{A} 21, \mathrm{~B} 1$ and $\mathrm{C}$.

\section{[...] in Status only displays photos, if there are interested customers, they usually Chat directly asking to be arranged as needed [...]}

Interviewee $\mathrm{C} 1$, representing sources A2, B, and B2, stated that social media does not allow personalization because consumers are too broad and open.

\section{[...] if I sell on Instagram I usually make it in general because the customers are too broad $[\ldots]$}

\section{Mobility}

Interviewees considered mobility as the ability to access content that can be done anywhere and anytime. Interviewee $\mathrm{C}$ had an opinion on this matter representing others.

\section{I can upload or delete content when I can and when I want, wherever I can when there is a product I want to sell $[\ldots]$}

It was supported by the same opinion from the A21, representing other interviewees, regarding WhatsApp Status.

\section{[...] I post items in Status when I can, usually when I relax at home or when there is an idea in a coffee shop [...]}

Interviewee A1 also thought the same thing for social media and market place.

[...] now everything can be posted via cellphones like Instagram or Bukalapak[...]

\section{E. Speed}

Speed is responded to as how quick contents can be uploaded to digital media as revealed by $\mathrm{C}$, which broadly represents other interviewees.

[...] posting via mobile phone can be directly read tai depending on internet connection. When posting classified ads in newspapers, usually for tomorrow's issue.

It was supported by the opinion of interviewee A representing A1 and C1, who feel the speed of posting on WhatsApp Status is faster than other social media.

\section{[...] posting on WhatsApp is faster}

than Facebook and Instagram [...]

However, interviewee B, representing A21, B2, and C, assumed that upload speeds on WhatsApp Status were the same as upload speeds on social media.

\section{[...] the speed of posting on WhatsApp is the same as on Instagram or Facebook, depending on the connection [...]}

It was supported by statements from interviewee $\mathrm{A}$ regarding the marketplace

[...] posting via mobile phone is just as fast as others, depending on the internet and its application $[\ldots]$

\section{F. Efficiency}

Interviewee considers efficiency as a product offering precisely according to the target customer. This opinion was expressed by A2 representing A, A21, B, C and C1.

[...] I know my customers and what they want, so I market what they want.

WhatsApp Status enables efficiency because resellers can estimate customers who might see their uploads on WhatsApp Status, as expressed by A2 representing A1 and B2.

\section{So far, marketing on Whatsapp Status is in line with the target customers and does not disappoint them. Those who see content, almost all who are in contact who really need my products. Those who buy my products are friends, relatives, or neighbors.}

Interviewee $\mathrm{A} 21$ representing $\mathrm{C}$ and $\mathrm{C} 1$ stated that social media had no efficiency because marketing was done in general.

\section{[...] not necessarily if marketing on}




\author{
Instagram or Facebook because the \\ customers are too diverse, so post it in \\ general $[\ldots]$
}

Interviewee A21 continued his opinion that if efficiency is related to the ease of uploading content, then all applications on smartphones allow efficiency.

\section{[...] but efficiency can be seen from the ease of displaying content. I think all applications are efficient $[\ldots]$}

\section{G. Enhanced Relationships}

Enhanced relationships are responded to as an increase in the level of persuasion to prospective customers to become a service for regular customers, as revealed by interviewee $\mathrm{A}$ representing others.

[...] right marketing can inspire consumers to become customers.

WhatsApp Status enables enhanced relationships because only users whose numbers are stored in the phonebook can see the Status, as revealed by interviewee B1 representing $\mathrm{A} 21$ and $\mathrm{C}$.

[...] so that the target customer can see the status, I will save the number and advise him to save my number so that from just knowing he can become a consumer then becoming a regular customer.

Interviewee B2 thought more or less the same as others.

\section{[...] many new prospective customers who know from word of mouth, from family or friends who are on WhatsApp contact numbers. If they are interested, I invite them to chat first and provoke them to see the Status.}

Interviewee A21, representing B and C, had the opinion that Instagram and Facebook do not allow for enhanced relationship because the followers are too diverse.
[...] Instagram and Facebook cannot improve relationships because usually the followers are not clear, usually they become consumers because they ask on WhatsApp.

The same opinion applies to the marketplace because consumers are too broad, as expressed by B2 representing A1 and B.

\section{[...] selling at Bukalapak is common for those who want to buy. To be a customer, it seems difficult $[\ldots]$}

\section{H. Strategic Implications}

Interviewees have the opinion that strategic implications are the next step that must be taken where A represents A1 and A2 linked it to the situation if products were no longer in demand.

WhatsApp Status can be used for market
tests. If around no one asks, I usually say
hello, give a tester, and give a review. But
if there is still no message, the product
means "bad". So for the next time I ignore
the product and turn it to the next
product.

While interviewee B, representing A1 and B2, had the opinion that the strategic implication is to use WhatsApp Status to ensure the current market trends.

[...] for example, I know the item that is selling, then I put it on WhatsApp Status.

Interviewee B, representing A1 and B2, added that Bukalapak can also be used to ascertain current market trends.

\section{[...] I also market at Bukalapak, stock a little first to see whether the merchandise will sell or not [...]}

While other interviewees responded to the strategic implications as a plan for product sales, as revealed by $\mathrm{C}$, representing $\mathrm{B} 1$ and $\mathrm{A} 21$.

\section{[...] I can sell anything, but I still sell products that I know. I'm looking for more customers $[\ldots]$}

And interviewee $\mathrm{C}$ had opinion that Instagram and Facebook allow strategic implications. [...] just like Instagram 


\section{What Whatsapp Status Enables Reseller to Do as Channel}

or Facebook to find customers [...]

\section{Attachment Theory}

Interviewee A provided an implicit definition of attachment representing A1, A2, B2, C1 relating to customer support for the product being offered.

[...] I hope when I promote the product, the customer will respond well.

In this regard, interviewee A emphasized the attachment that was the response expected only came from known people.

The customer I know who is the one who gave a good response. WhatsApp allows this, the person I know, the number I know. On Instagram there is something I don't know even though it can be limited by private account.

Interviewees believe that generally everyone is a WhatsApp user. Interviewee $\mathrm{C}$ stated that opinion representing others.

\section{[...] everyone I know has WhatsApp, every number I save must have WhatsApp.}

It is followed by a statement that the number stored in the phonebook is the number of the identified individual, as stated by $\mathrm{C}$ representing $\mathrm{A} 2, \mathrm{~B}$, and $\mathrm{B} 1$.

I keep the number of parties I know so they can be contacted via WhatsApp.

WhatsApp Status allows resellers to deliver product information that is marketed without having to send it personally, as expressed by interviewee B2 representing others.

\section{[...] advertise on WhatsApp Status} directly to all and you don't need to send one by one. No need to feel bad or feel rejected.

Interviewee $\mathrm{A}$, representing $\mathrm{A} 2, \mathrm{~A} 21, \mathrm{C}, \mathrm{C} 1$ tend to use WhatsApp Status because it assumes that everyone is a WhatsApp user so that it can be used as a marketing channel and only users who store numbers in the phonebook can see Status so that the customer scope does not widen. This is different from Instagram or Facebook..

I like to advertise on Instagram or on Facebook but for certain products it is better to advertise on WhatsApp Status where it can only be seen by people I know. Comments on Instagram and others can be seen by people, while the response on WhatsApp is personal.

Interviewee A1, representing B and B2, utilizing Bukalapak and OLX as marketing channel besides WhatsApp Status but feels that marketing through WhatsApp Status promises more sales because it recognizes its customers.

\section{[...]when I sell products on WhatsApp, it's definitely better because I know who my customers are. If I sell at Bukalapak, I don't know my customers, and I can't provoke them to respond and buy, unlike WhatsApp.}

Interviewee A21, B1, C had an opinion that the marketplace is not an appropriate channel to offer service products because consumers in the marketplace are difficult to recognize. This opinion was represented by $\mathrm{C}$.

I market service products through WhatsApp Status because I know who the consumers are, so they will most likely use the services I offer. I do not market my services through Tokopedia or Bukalapak because in my opinion the customer is difficult to be recognized

\section{J. Channel}

Interviewee A, representing A1, A2, A21, B, and B2, responded to the channel as a place to market and sell products.

\section{[...] channels are a means of marketing products that are usually through social media $[\ldots]$}

Interviewees have an implicit opinion that WhatsApp Status only has a function in the awareness stage to increase customer awareness about the products or services offered by resellers, as revealed by $\mathrm{B}$ representing $\mathrm{B} 2$ and $\mathrm{C}$, related to interactivity where the evaluation process occurs via WhatsApp Chat.

\section{[...] if someone wants to know about my} product in status, then he can chat to ask me $[. .$. 
WhatsApp Status is not possible as a channel for customers to buy products as implied by $\mathrm{B} 2$ representing $\mathrm{A} 2$ and $\mathrm{C} 1$.

\section{[...] those who are interested can transfer, and I} send bags or clothes through shipping services.

It was supported by the response implied by interviewee A21 that the transfer of value proposition cannot be done through WhatsApp Status.

\section{[...] usually customers come directly to my shop or I use Go-Send after the money is transferred plus shipping costs.}

WhatsApp Status does not allow for after sales stages because this stage is a process of interactivity that usually occurs through WhatsApp Chat, as revealed by interviewee A.

\section{$[\ldots]$ if customers like it, they will definitely chat me. If they don't like it, then they also chat me. Because generally I know them.}

WhatsApp Status has a reverse function in the awareness and evaluation stages compared to Facebook or Instagram, as revealed by interviewee $\mathrm{A}$.

\section{[...] WhatsApp is for Chat but can post products in Status, if Instagram can post products and comments can be via direct message. Facebook also like that.}

Interviewee A1 stated that Bukalapak and OLX have enabled different channel stages compared to WhatsApp Status in terms of evaluation, and after sales..

\section{The difference between the marketplace and WhatsApp is that in Bukalapak or $O L X$, I can provide an explanation of the product, reply to customer questions, and also complains with customers.}

\section{RESUlt AND DiscuSSION}

This research discussed WhatsApp Status as one of the features of WhatsApp by focusing on WhatsApp Status capabilities that can be used as a marketing channel, and investigating the possibility of other capabilities related to channel functions, and understanding the background of using WhatsApp Status by resellers. To strengthen the position of WhatsApp Status as the subject of research, researchers intentionally included opinions from interviewee regarding Facebook and Instagram, which are social media, and Bukalapak, which is a marketplace, whereas OLX, which is a marketplace, was not included in the discussion due to limited data for validation purposes.

Basically, WhatsApp Status is used as a marketing channel by resellers because it is based on the opinion of the sources that WhatsApp is the most widely used chat application. This is in accordance with the results of digital media surveys (Kemp, 2018).

Interviewees had opinion that WhatsApp is a widely used chat, thus it is used by resellers as a marketing media. This research was conducted to find out more from WhatsApp Status, besides being a widely used chat application, which focuses on its ability as a marketing channel that can help resellers to market their products. To understand this, this research was conducted using attachment theory, and the concept of digital media reliability related to interactivity, multichannel marketing, personalization, mobility, speed, efficiency, relationship enhancement, and strategic implications associated with channel concepts in finding empirical conclusions based on data from the resource person.

Interviewees stated that WhatsApp users are able to view the content in the Status of other users on the condition that between users must save each other's number in their respective phonebook. Due to that reason, there is an emotional bond built on the belief that those who can respond to marketed content are users who know each other. In this case Interviewees also stated that resellers as WhatsApp Status users do not need to send marketing content privately, which is usually done through WhatsApp Chat, so that resellers do not need to worry about rejection or neglect. And consumers don't need to feel the need to open content on WhatsApp Status if they feel uninterested. Interviewees believes that WhatsApp Status is different from Facebook, Instagram, and Bukalapak where content can be seen by all known and unknown people so there is no attachment factor

Interviewees provided information that WhatsApp Status does not allow interactivity because question and answer occurs via WhatsApp Chat. However, the interactivity that occurs through WhatsApp Chat is the result of the bait that occurs because the reseller uploads content on WhatsApp Status, and in the end the reseller can filter customers who are interested in the products of the goods or services offered. Interviewees believe that Facebook, Instagram, and Bukalapak have interactivity.

WhatsApp Status has facilities to support multichannel marketing in the form of hyperlinks to other media, but this can be done only if the content is in the form of text where the interviewees considered the text content would not attract the customer's attention, thus this facility has not been used. Facebook, Instagram and Bukalapak support multichannel marketing where users can include the link address in the marketed product information section.

Interviewees considered that WhatsApp Status is able to support personalization related to attachment theory where offers are made based on customer generally known preference. However, some 


\section{What Whatsapp Status Enables Reseller to Do as Channel}

interviewees assumed that WhatsApp Chat has a role in accommodating customer desires which is supporting a personal approach or personalization. Interviewees believe that Facebook, Instagram and Bukalapak do not allow personalization because their customers are not personally known.

WhatsApp Status supports mobility where interviewees believe that uploading content can be done anywhere and anytime. The resource person realized that WhatsApp Status is part of the WhatsApp application that is intended for mobile devices. Likewise, Facebook, Instagram and Bukalapak have mobile applications that enable mobility.

Interviewees had the opinion that the speed of uploading content on WhatsApp Status is fast, but it relies on the connection to the internet and the running of WhatsApp itself. The interviewees compared the speed of marketing the product through WhatsApp Status compared to conventional marketing where conventional marketing was not necessarily instant. Facebook, Instagram and Bukalapak that have content upload speeds depend on internet connectivity and the application itself.

WhatsApp Status enables efficiency where only the user whose number is stored by the reseller and who stores the number of resellers who can view WhatsApp Status content so that marketing can only be seen by customers that indirectly intended by resellers. Facebook, Instagram and Bukalapak are considered to have no efficiency related to their broad audience, but when viewed from the ease of use of the application, Facebook, Instagram and Bukalapak have efficiency.

WhatsApp Status enables enhanced relationships where it is also related to the theory of attachment where customers innately form and maintain proximal attachments with resellers, as revealed by interviewees that from just knowing the product, the user can eventually become a regular customer. Facebook, Instagram and Bukalapak do not allow for enhanced relationships as WhatsApp Status because the viewers are too diverse.

The interviewees responded to the strategic implications as an action to use WhatsApp Status as a benchmark for further planning, both in ensuring current market trends, determining steps in bad sales situations, or determining sales plans based on market share development. Facebook, Instagram and Bukalapak have strategic implications related to the ability to ascertain the prevailing market trends.

Interviewees believe that WhatsApp Status only allows marketing (awareness), not to be a medium for consumers to ask questions or comments about products (evaluation and after sales), or for product sales (purchase and delivery). Whereas according to them too, Facebook, Instagram and Bukalapak allow for marketing, evaluation, and aftersales.

\begin{tabular}{|l|l|l|l|l|}
\hline No & Research Subject & WhatsApp Status & Social Media & Market Place \\
\hline 1 & Attachment & Yes & No & No \\
\hline 2.1 & Interactivity & No & Yes & Yes \\
\hline 2.2 & Multichannel Marketing & Yes/No & Yes & Yes \\
\hline 2.3 & Personalization & Yes & No & No \\
\hline 2.4 & Mobility & Yes & Yes & Yes \\
\hline 2.5 & Speed & Yes & Yes & Yes \\
\hline 2.6 & Eficiency & Yes & Yes/No & Yes/No \\
\hline 2.7 & Enhanced Relationship & Yes & No & No \\
\hline 2.8 & Strategic Implication & Yes & Yes & Yes \\
\hline 3.1 & Awareness & Yes & Yes & Yes \\
\hline 3.2 & Evaluation & No & Yes & Yes \\
\hline 3.3 & Purchase & No & No & No \\
\hline 3.4 & Delivery & No & No & No \\
\hline 3.5 & After Sale & No & Yes & Yes \\
\hline
\end{tabular}

Tabel 2. Findings

\section{CONCLUSION AND Limitations}

Based on the discussion, as a result of research involving interviewees, the conclusion that can be taken by the researcher is that Whatsapp Status is an appropriate application feature as a marketing channel for resellers.

As a feature of the WhatsApp application intended for smartphones, WhatsApp Status can help resellers upload content that can be done quickly, anywhere, and anytime depending on the connection to the internet and the functioning of WhatsApp itself. In addition, WhatsApp Status allows resellers to help ensure market trends, or determine sales plans as strategic implications. But because WhatsApp Status is only one of the features of the WhatsApp application, WhatsApp Status does not allow interaction between resellers and consumers, because interactions occur in the WhatsApp Chat feature. Similarly, hyperlinks to other social media are not possible on WhatsApp Status but are

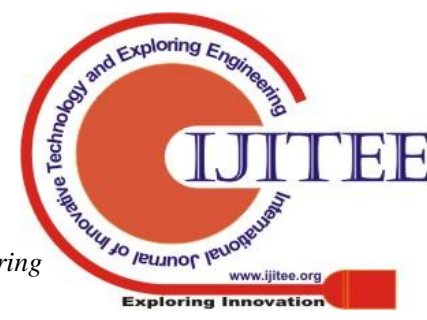


possible on WhatsApp Chat.

Because interactions occur on WhatsApp Chat, WhatsApp Status does not allow channels for consumers to evaluate products or after-sales services. WhatsApp Status is only possible as a marketing channel to raise awareness. Meanwhile, to make product purchases, consumers can do it through third parties who are usually in the form of financial companies, and for product delivery, resellers can directly or through third parties, usually in the form of goods delivery companies.

The ability of WhatsApp Status as a marketing channel is no different from Facebook, Instagram, as social media, and Bukalapak, as a marketplace. But the main reason for resellers to use WhatsApp Status as a marketing channel, which is not possible on Facebook, Instagram and Bukalapak, is that besides WhatsApp is the most widely used application, resellers know who their customers are, and resellers can market their products to any WhatsApp user recorded in a reseller phonebook without having to be directed to a particular user or group. WhatsApp Status allows resellers and consumers to get to know each other, so there is an emotional bond where reseller hope that content delivered via WhatsApp Status will get a good response from consumers. This emotional bond that forms the basis of WhatsApp Status allows reseller to upload content efficiently that enables personalization, in the form of a personal approach, which leads to increased relationships from consumers to customers. The above conclusions are followed by limitations that the interviewees in this study are limited to resellers, need further research to find out whether WhatsApp Status allows marketing channels for start-ups or in the field of entrepreneurship that emphasize attachment theory and the concept of channel stages in digital media that offer several things to allow the use of WhatsApp Status as a marketing channel. And it needs to be continued to strengthen this research which is suggested in quantitative form by comparing WhatsApp Status with other chat applications, on social media, or on the marketplace as a marketing channel to achieve an understanding of effectiveness or limitations that enable WhatsApp Status as a digital marketing channel.

\section{REFERENCES}

1. Bowlby, J. (1969). Attachment and Loss: Volume I Attachment (2nd ed., Vol. 1). New York: Basic Books.

2. Broch, C., Lurati, F., Zamparini, A., \& Mariconda, S. (2017). The Role of Social Capital for Organizational Identification: Implications for Strategic Communication. International Journal of Strategic Communication, 12(1), 46-66.

3. Brock, D. (2009). Aftersales Management: Creating a Successful Aftersales Strategy to Reduce Costs, Improve Customer Service and Increase Sales. London, United Kingdom: Kogan Page Publishers.

4. Bryman, A. (2012). Social Research Methods (4th ed.). New York: Oxford University Press Inc. Bryman, A., \& Bell, E. (2011). Business Research Methods 3e. Oxford, UK: OUP Oxford.

5. Bukalapak. (2018). Tentang Bukalapak. Retrieved November 2, 2018, from https://www.bukalapak.com/about

6. Caers, R., De Feyter, T., De Couck, M., Stough, T., Vigna, C., \& Du Bois, C. (2013). Facebook: A literature review. New Media and Society.

7. Chellappa, R. K., \& Sin, R. G. (2005). Personalization versus Privacy: An EmpiricalExamination of the Online Consumer' $\mathrm{s}$ Dilemma. Information Technology and Management, 6(2-3), 181-202.

8. Church, K., \& de Oliveira, R. (2013). What's up with whatsapp?: comparing mobile instant messaging behaviors with traditional SMS. 15th International Conference on Human- Computer Interaction with Mobile Devices and Services (MobileHCI'13), 352-361.

9. Couldry, N. (2012). Media, Society, World: Social Theory and Digital Media Practice.

10. Cambridge: Polity.

11. Creswell, J. W. (2014). Research Design: Qualitative, Quantitative, and Mixed Methods Approaches (4th ed.). California: SAGE Publications, Inc.

12. Daymon, C., \& Holloway, I. (2010). Qualitative Research Methods in Public Relations and Marketing Communications (2nd ed.). Routledge.

13. Denzin, N. K., \& Lincoln, Y. S. (2003). Strategis of Qualitative Inquiry (2nd ed.). California: SAGE Publications, Inc.

14. Edwards, D., Ho, L., \& Choi, S. (2017). Media , Mobilities and Identity in East and Southeast Asia: Introduction. Cultutral Studies Review, 23(1), 60-68.

15. Fill, C. (2009). Marketing Communications: Interactivity, Communities and Content. Harlow, Edinburgh: Pearson Education Limited.

16. Fogli, L., \& Ukei, J. (2005). Customer Service Delivery: Research and Best Practices. Hoboken, New Jersey: John Wiley \& Sons.

17. Galloway, L., Rowbotham, F., \& Azhashemi, M. (2012). Operations Management in Context.

18. Abingdon, United Kingdom: Routledge.

19. Jordan, Z. (2016). The effect of promotion mix elements on Consumers Buying Decisions of Mobile Service: The case of Umniah Telecommunication Company at Zarqa city- Jordan. European Journal of Business and Management, 8(5), 94-100.

20. Kaniewska-Sċba, A., \& Pilarczyk, B. (2014). Negative Effects of Personalization in Direct

21. Marketing. International Journal of Arts \& Sciences, 7(2), 89-98.

22. Karjaluoto, H., \& Mustonen, N. (2015). The Role of Digital Channels in Industrial Marketing Communications. Journal of Business \& Industrial Marketing, 30(6), 703-710.

23. Kemp, S. (2018). Digital In 2018 In Southeast Asia.

24. Kern, F. G. (2018). The Trials and Tribulations of Applied Triangulation: Weighing Different Data Sources. Journal of Mixed Methods Research, 12(2), 166-181.

25. Kothari, C. R. (2004). Research Methodology: Methods \& Techniques. New Age International

26. (2nd ed.). New Delhi: New Age International Publisher.

27. Lee, E., Lee, J.-A., Moon, J. H., \& Sung, Y. (2015). Pictures Speak Louder than Words: Motivations for Using Instagram. Cyberpsychology, Behavior, and Social Networking 18(9), 552-556.

28. Lister, M., Dovey, J., Giddings, S., Grant, I., \& Kelly, K. (2009). New Media: A Critical Introduction. (M. Lister, Ed.). New York: Taylor \& Francis.

29. Liu, Y., \& Shrum, L. J. (2002). What is Interactivity and is It Always Such a Good Thing? Implications of Definition, Person, and Situation for the Influence of Interactivity on Adveritising Effectiveness. Journal of Advertising, 31(4), 53-64.

30. Montag, C., Błaszkiewicz, K., Sariyska, R., Lachmann, B., Andone, I., Trendafilov, B., ... Markowetz, A. (2015). Smartphone usage in the 21st century: Who is active on WhatsApp? BMC Research Notes, 8(1), 4-9.

31. Mulhern, F. (2009). Integrated marketing communications : From media channels to digital

32. connectivity. Journal of Marketing Communications, 15(2009), 85-101.

33. Ng, D. (2017). Evolution of Digital Payments: Early learnings from Singapore's cashless payment drive. Journal of Payments Strategy \& Systems, 11(4), 306-312.

34. OLX. (2018). Tentang OLX. Retrieved December 2, 2018, from https://help.olx.co.id/hc/id/articles/213746523-Tentang-OLX

35. Osterwalder, A., \& Pigneur, Y. (2010). Business Model Generation: A Handbook for Visionaries, Game Changers, and Challengers. (Y. Pigneur, Ed.). Hoboken, New Jersey: John Wiley \& Sons.

36. Ouwersloot, H., \& Duncan, T. (2008). Integrated Marketing Communication (European).

37. Berkshire: McGraw-Hill Education.

38. Palmatier, R. W. (2000). Relationship Marketing. Emerging Perspectives of Services Marketing.

39. Cambridge, Massachusetts: Marketing Science Institute.

40. Rangaswamy, A., \& Bruggen, G. H. Van. (2005). Opportunities and Challenges in Multichannel Marketing: An Introduction to the Special Issue. Journal of Interactive Marketing, 19(2), 5-11. 
What Whatsapp Status Enables Reseller to Do as Channel

41. Sahu, S. (2014). An Analysis of WhatsApp Forensics in Android Smartphones. International Journal of Engineering Research, 5013(3), 349-350.

42. Saunder, M. N. K., Lewis, P., \& Thornhill, A. (2015). Research Methods for Business Students

43. (7th ed.). London, England: Pearson Education Limited.

44. Silverman, D. (2010). Doing Qualitative Research. California: SAGE Publications, Inc.

45. Sullivan, Y. W., \& Kim, D. J. (2018). Assessing the effects of consumers' product evaluations and trust on repurchase intention in e-commerce environments. International Journal of Information Management, 39(December 2017), 199-219.

46. Sundqvist, E., Backlund, F., \& Chronéer, D. (2014). What is Project Efficiency and Effectiveness? Procedia - Social and Behavioral Sciences, 119, 278-287. 